\title{
A One-Pot Three-Component Synthesis and Investigation of the In Vitro Mechanistic Anticancer Activity of Highly Functionalized Spirooxindole-Pyrrolidine Heterocyclic Hybrids
}

\author{
Raju Suresh Kumar*(D), Dhaifallah M. Al-thamili, Abdulrahman I. Almansour, \\ Natarajan Arumugam $(D)$ and Faruq Mohammad $(D)$ \\ Department of Chemistry, College of Science, King Saud University, P.O. Box 2455, Riyadh 11451, Saudi Arabia; \\ 442106623@ksu.edu.sa (D.M.A.-t.); almansor@ksu.edu.sa (A.I.A.); anatarajan@ksu.edu.sa (N.A.); \\ fmohammad@ksu.edu.sa (F.M.) \\ * Correspondence: sraju@ksu.edu.sa \\ Academic Editor: Gian Cesare Tron \\ Received: 20 October 2020; Accepted: 24 November 2020; Published: 27 November 2020

\begin{abstract}
With an aim to develop more effective and affordable anticancer agents possessing a unique mechanism of action, we designed and synthesized derivatives of spirooxindole-pyrrolidine heterocyclic hybrids in good yields through a one-pot three-component $(3+2)$ cycloaddition strategy. The synthesized compounds were characterized thoroughly for the physicochemical properties by making use of FT-IR, NMR spectroscopy, and mass spectrometry. Further, these compounds have been evaluated for the influence of anticancer activity against HepG2 cells up to $200 \mu \mathrm{g} / \mathrm{mL}$ concentration. The highly active molecular scaffold was tested for the in-depth mechanistic studies, and it was found that the major pathway of cell death is apoptosis which occurs through the induction of reactive oxygen species followed by the involvement of caspases.
\end{abstract}

Keywords: multicomponent reaction; functionalized spirooxindole-pyrrolidine hybrids; anticancer activity; controlled cell death; apoptosis; ROS generation; caspase-3 activity

\section{Introduction}

Carcinogenesis, also termed as tumorigenesis or oncogenesis, is a complex biological multi-step encompassing process involving a series of physiological mechanisms, where the outcome is the growth of cancerous tumors that has the capacity to completely arrest normal functions of an organ [1]. The inhibition of normal organ functions in cancerous cells, in general, first occurs through the cell division, followed by an uncontrolled growth of mutated cells to form malignant tumors, which on later stages spread to nearby cells and even migrate to different sites of the body by making use of the lymphatic system or bloodstream. To reduce the uncontrolled growth of malignant and fast dividing cells, many different antiproliferative drugs with enhanced pharmacological activity and bioavailability are used; however, the prolonged use of such drugs may develop uterine and endometrial cancers [2]. To overcome these issues, various synthetic and natural anticancer drugs are being developed and introduced into the market. As the nonselective action of such developed anticancer drugs are associated with many side effects including the bone marrow suppression, alopecia, and nephrotoxicity, the necessity of developing novel drug entrants with improved effectiveness to target only cancer cells is emphasized.

The construction of novel drug entrants with improved physiochemical properties, pharmacologic effectiveness, and no or less toxicity in cancer treatment has been an essential subject in the drug 
development sector. Undeniably, the construction of such molecular frameworks through a facile synthetic methodology with cost-effective considerations is still a challenge for medicinal chemists and necessitates long-lasting efforts. One of the developed strategies in recent years is the amalgamation of two or more diverse pharmacophores into a sole molecular framework, documented as molecular hybridization [3-10]. The molecular hybridization becomes an effective approach to the design of new drug entrants and is based on the identification of pharmacophoric structural subunits via the suitable combination of these subunits, which provides a base for the design of novel heterocyclic hybrids that preserves the preselected features of parental prototypes. The prominent advantage of employing the molecular hybridization approach is to trigger diverse targets by a sole molecule, thus increasing the therapeutic effectiveness and bioavailability profiles. Promisingly, noteworthy results with a diverse group of heterocyclic hybrids have been elegantly recognized as a result of this approach [11-18].

Spiropyrrolidine oxindoles hold fascinating structural characteristics and robust bioactivity profiles to have appeared as promising synthetic targets, as these heterocyclic hybrids serve as very useful molecular architectures for the investigation of pharmacophore space by making use of diverse oriented synthesis that in turn results in the development of new drug entrants [19-24]. The literature reports discovered that the presence of $\alpha, \beta$-unsaturated ketone moiety in a piperidone molecular unit is an important functionality for the activity of piperidone derivatives. Besides, these compounds are investigated to be associated with both fluorescence and antitumor capacity and thus can be potential for cancer cell studies towards the development of novel therapeutic pathways involving fluorescent drugs [25]. However, the literature reports provide the information that the combination of these biologically important structural units in a single molecular framework has not been widely studied. Therefore, based on the excellent biological profiles of spiropyrrolidine oxindoles, piperidone, and $\alpha, \beta$-unsaturated ketones, we wondered the molecular hybridization of these structural subunits in a single molecule that might create novel anticancer drugs. Hence, in this research, we aimed to discuss our efforts in the design and development of more potent analogues for the cancer chemotherapy.

\section{Results and Discussion}

\subsection{Chemistry}

In our initial attempt, the synthesis of $\mathrm{N}$-unsubstituted bisarylmethylidene-tetrahydropyridinones 3 (a-h) was performed according to the literature report as provided by Dimmock et al. [26]. With the compounds $\mathbf{3}(\mathbf{a}-\mathbf{h})$ in hand, the dipolarophiles and $N$-substituted bisarylmethylidene-tetrahydropyridinones $\mathbf{5}(\mathbf{a}-\mathbf{h})$ required for the present study were synthesized in a $85-90 \%$ yield range through the alkylation of $\mathbf{3}(\mathbf{a}-\mathbf{h})$ with 2-(chloromethyl)pyridine hydrochloride in the presence of $\mathrm{K}_{2} \mathrm{CO}_{3}$ (Scheme 1) $[27,28]$. The azomethine ylide was generated in situ from isatin and phenylglycine via decarboxylative condensation. Our approach to the synthesis of spirooxindole molecular scaffold employing isatin 6 and (L)-Phenylglycine 7 was based on a multicomponent reaction strategy involving the 1,3-dipolar cycloaddition reaction between $\mathrm{N}$-pyridinylmethyl-bisarylmethylidenepyridinones $\mathbf{5}(\mathbf{a}-\mathbf{h})$ and azomethine ylide generated in situ from 6 and 7 as outlined in Scheme 1.

Initially, the reaction optimization for this one-pot $(3+2)$ cycloaddition reaction was done by performing the reaction of an equimolar mixture of $\mathbf{5 e}, \mathbf{6}$, and $\mathbf{7}$ under reflux in different solvents, including ethanol, methanol, dioxane, methanol/dioxane, and acetonitrile. The reaction progress was observed by thin layer chromatography, after the completion of the reaction, as evidenced by the disappearance of the substrates and the formation of a sole reaction product by thin-layer chromatography (TLC) analysis. Fifty milliliters of ice-cold water were added to the reaction mixture, and the precipitated solid was filtered, washed repeatedly with water and then dried under vacuum to obtain the cycloadduct 8e. The obtained spirooxindole-pyrrolidine heterocyclic hybrid was purified either by crystallization using acetonitrile or by column chromatography employing hexane-ethyl 
acetate $(v / v: 3: 2)$ as an eluent. Among the solvents used, methanol was found to be the optimal solvent with respect to yield ( $88 \%$ ) and reaction time $(2 \mathrm{~h})$. Hence, all the subsequent reactions starting with different aryl ring-substituted dipolarophiles $\mathbf{5}(\mathbf{b}-\mathbf{h})$ were performed under this optimized reaction condition. All these reactions furnished the corresponding spirooxindole-pyrrolidine heterocyclic hybrids 8 (a-d and $\mathbf{f}-\mathbf{h})$ in good to excellent yields (85-90\%).
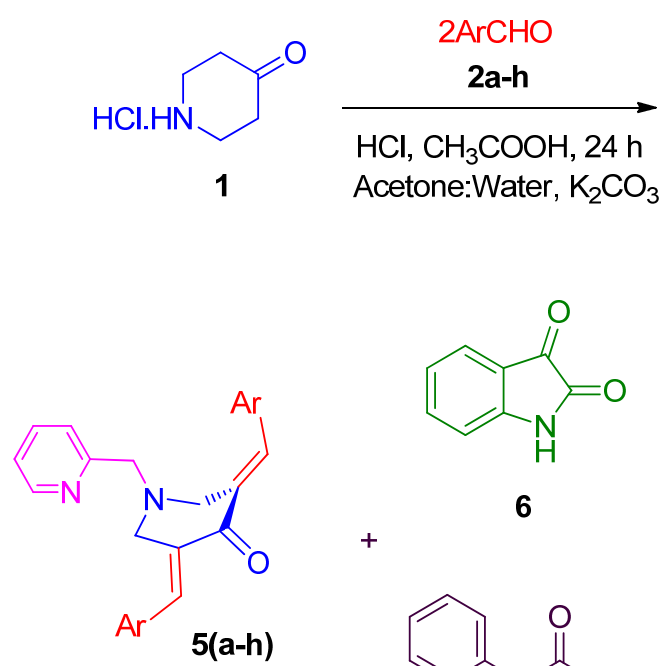<smiles>O=C1Nc2ccccc2C1=O</smiles>

6

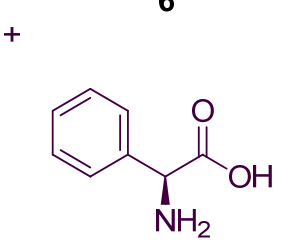

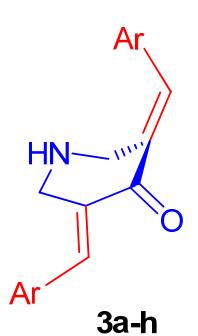

$3 a-h$

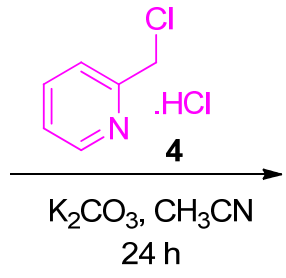

$24 \mathrm{~h}$

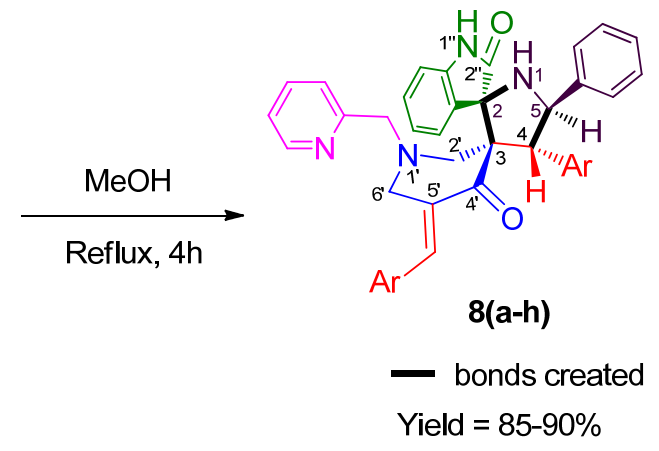

7

Scheme 1. Synthesis of spirooxindole-pyrrolidine molecular scaffolds $\mathbf{8}(\mathbf{a}-\mathbf{h})$.

This cycloaddition reaction proceeded regio- and stereoselectively, as only one diastereoisomeric cycloadduct is formed despite the presence of multiple stereocenters and afforded the compounds 8 (a-h) in good yields. The spirooxindole-pyrrolidine molecular scaffolds were obtained through a process which involved the formation of two $\mathrm{C}-\mathrm{C}$ bonds, one $\mathrm{C}-\mathrm{N}$ bond, and four contiguous stereocenters.

The spirooxindole-pyrrolidine molecular scaffolds 8 were studied thoroughly by making use of various instrumental techniques involving FT-IR, one-dimensional (1D) and two-dimensional (2D) NMR spectroscopy, and mass spectrometry (Figure 1 and +Electronic Supplementary Information). In the FT-IR spectrum of 8e, the noticeable infrared absorption peaks at $v_{\max }$ of 2360, 2341, 1698, and $1597 \mathrm{~cm}^{-1}$ were referred to $\mathrm{N}-\mathrm{H}, \mathrm{C}=\mathrm{O}$, and $\mathrm{C}=\mathrm{C}$ groups, respectively. In the ${ }^{1} \mathrm{H}$ NMR spectrum, the $\mathrm{H}-4$ proton furnished a doublet at $4.68 \mathrm{ppm}(J=11.0 \mathrm{~Hz})$. This is further established by its Heteronuclear Multiple Bond Correlation (HMBC) with the carbonyl carbon C-4' at 199.35 ppm. The H,H-Correlation Spectroscopy (H,H-COSY) of H-4 proton allocated the doublet at $5.43 \mathrm{ppm}(\mathrm{J}=11.0 \mathrm{~Hz})$ to its coupling partner $\mathrm{H}-5$. The $\mathrm{C}, \mathrm{H}-\mathrm{COSY}$ correlation of $\mathrm{H}-4$ and $\mathrm{H}-5$ with the carbon signals at $56.81 \mathrm{ppm}$ and 64.36 ppm assigned these peaks to C-4 and C-5, respectively. Further, the HMBC of H-4 allocated the carbon signal at $57.03 \mathrm{ppm}$ to C-2'. The C,H-COSY correlation of C-2' assigned the doublet at $2.13 \mathrm{ppm}$ $(J=13.0 \mathrm{~Hz})$ and the doublet of doublets at $3.63 \mathrm{ppm}(J=13.0$ and $2.5 \mathrm{~Hz})$ to $2^{\prime}-\mathrm{CH}_{2}$. The doublet of doublets at $2.97 \mathrm{ppm}(J=15.0$ and $3.0 \mathrm{~Hz})$ and the doublet at $3.42 \mathrm{ppm}(J=15.0 \mathrm{~Hz})$ were assigned to $6^{\prime}-\mathrm{CH}_{2}$. The remaining doublets at $3.37 \mathrm{ppm}$ and $3.79 \mathrm{ppm}(J=13.5 \mathrm{~Hz})$ were due to $7^{\prime}-\mathrm{CH}_{2}$. The singlets at 2.26 and $2.27 \mathrm{ppm}$ were due to the two $-\mathrm{H}_{3}$ group substituted at the aromatic ring, while the aromatic ring protons appeared as doublets and multiplets around 6.61 to $8.45 \mathrm{ppm}$. The carbon signals at 54.21 and 63.90 ppm were allocated to $C-6^{\prime}$ and $C-7^{\prime}$, respectively, whereas the signals at $66.87 \mathrm{ppm}$ and 72.17 ppm were due to the spiro carbons C-3 and C-2, respectively. The oxindole carbonyl carbon 
appears at $180.42 \mathrm{ppm}$. The selected ${ }^{1} \mathrm{H}$ and ${ }^{13} \mathrm{C}$ chemical shifts of $8 \mathrm{e}$ are shown in Figure 1 . A peak at $603\left[\mathrm{M}^{+}\right]$in the mass spectrum of 8 a confirmed the structure deduced from spectroscopic studies.

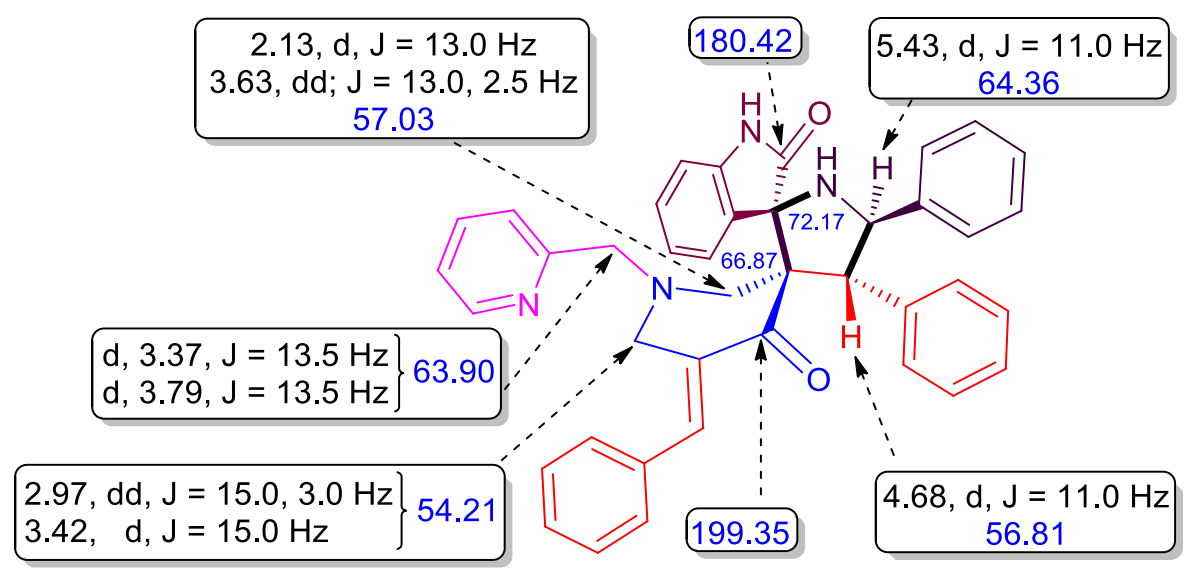

Figure 1. Selected ${ }^{1} \mathrm{H}$ and ${ }^{13} \mathrm{C}$ NMR chemical shifts of $8 \mathbf{e}$.

A probable mechanism accounting for the formation of molecular scaffolds $\mathbf{8}(\mathbf{a}-\mathbf{h})$ is shown in Scheme 2. Presumably, the reaction of isatin and (L)-Phenylglycine via decarboxylative condensation afforded the azomethine ylide which may exist in the resonating forms 9 and $\mathbf{1 0}$. Then, the regioselective addition of ylide $\mathbf{9}$ to one of the exocyclic $\mathrm{C}=\mathrm{C}$ bonds of $\mathbf{5}(\mathbf{a}-\mathbf{h})$, with the addition of nucleophilic carbon of the azomethine ylide to the more electron-deficient $\beta$-carbon of the dipolarophile to afford the cycloadducts $\mathbf{8}(\mathbf{a}-\mathbf{h})$. The other possible regioisomer $\mathbf{1 1}$ formed by the addition of azomethine ylide 10 to the dipolarophile was not observed even in traces. The nonformation of this regioisomer may be attributed to the existence of steric hindrance experienced by the aryl and oxindole rings.

\subsection{Biology}

The in vitro studies of cell viability due to the action of the tested compounds $\mathbf{8}(\mathbf{a}-\mathbf{h})$ at the treatments in the concentration range of $12.5-200 \mu \mathrm{g} / \mathrm{mL}$ over two different time periods of 24 and $48 \mathrm{~h}$ to HepG2 cancer cells are shown in Figures 2 and 3. It can be noted from the results analysis that all the tested compounds maintained certain levels of activity against the cancer cells and this activity was increased with regards to an increased concentration and an increased incubation period of the tested compounds, as against the positive control of melphalan $(15 \mu \mathrm{g} / \mathrm{mL})$ and the negative control of the cells having no treatment. Table 1 indicates the concentration required for $50 \%$ of cell death $\left(\mathrm{IC}_{50}\right)$ values following the treatment of compounds $\mathbf{8}(\mathbf{a}-\mathbf{h})$ for the HepG2 cancer cells for 24 and $48 \mathrm{~h}$ periods and reveals the highest activities for the two compounds $8 \mathrm{f}$ and $8 \mathrm{~g}$ and the least activity for the compound 8e. Among the two most active compounds of $\mathbf{8 f}$ and $\mathbf{8 g}$, whether one took the lead over the other depended upon the incubation time. That is, under the $24 \mathrm{~h}$ incubation time, the compound $8 \mathrm{f}$ is most active, as we observed the $\mathrm{IC}_{50}$ value of approximately $43.46 \mu \mathrm{g} / \mathrm{mL}$, while at the $48 \mathrm{~h}$ incubation period, the compound $8 \mathrm{~g}$ has an $\mathrm{IC}_{50}$ value of approximately $12.79 \mu \mathrm{g} / \mathrm{mL}$. Thus, based on the MTT anticancer activity assay, the observed $\mathrm{IC}_{50}$ value order during the $24 \mathrm{~h}$ incubation period followed the order of $8 f>8 g>8 b>8 a>8 h>8 c>8 d>8 e$, while for the 48 h period it is $8 g>8 f>8 a>8 b>8 h>$ $8 \mathrm{c}>8 \mathrm{~d}>8 \mathrm{e}$.

To test the behavior of our synthesized compounds towards the noncancer cells, the two most active compounds, $8 \mathbf{f}$ and $8 \mathrm{~g}$ were tested against the L929 cells over a concentration range of $12.5-200 \mu \mathrm{g} / \mathrm{mL}$ for the highest incubation period of $48 \mathrm{~h}$ (as shown in Figure 4 and the values tabulated in Table 1). From the analysis of the experimental results, it can be noted that the two compounds exhibited an approximately similar activity and the considerable activity was observed only at and above the concentration of $100 \mu \mathrm{g} / \mathrm{mL}$. The $\mathrm{IC}_{50}$ values of the compounds $8 \mathrm{f}$ and $8 \mathrm{~g}$ were measured to be 72.12 and $153.89 \mu \mathrm{g} / \mathrm{mL}$, respectively, and these values were higher as compared to the $\mathrm{IC}_{50}$ values 
observed for the same compounds but with the cancer cells (HepG2). This indicated that the controlling of cancer cells by the treatment of compounds $8 \mathrm{f}$ and $8 \mathrm{~g}$ and with negligible damage to the noncancer cells can be possible and this is one of the important criteria in cancer chemotherapy. In addition, since our aim was to examine the probable mechanism of cell death produced by the most active molecular scaffold, we selected the compound $8 \mathrm{~g}$ to perform the other molecular biology studies which required only the least concentration for the observation of cell death.
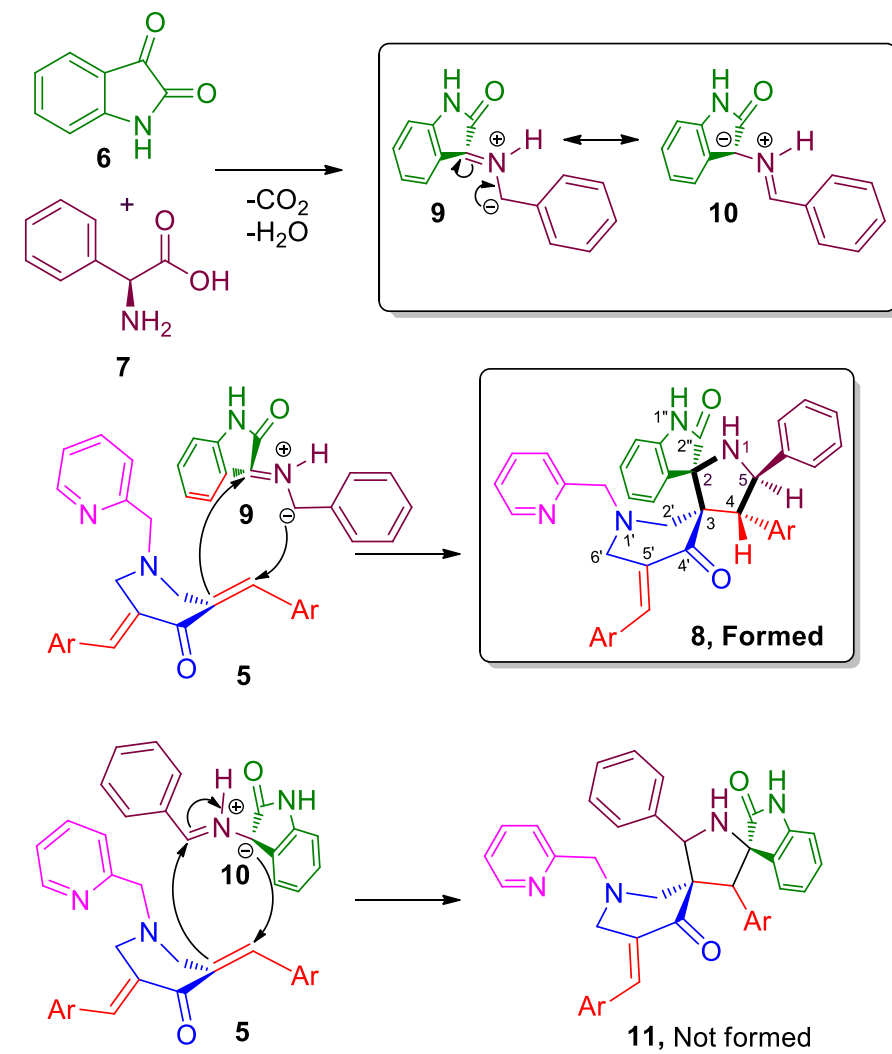

Scheme 2. Schematic representation of the plausible mechanism for the region-selective formation of spirooxindole-pyrrolidine molecular scaffolds 8.

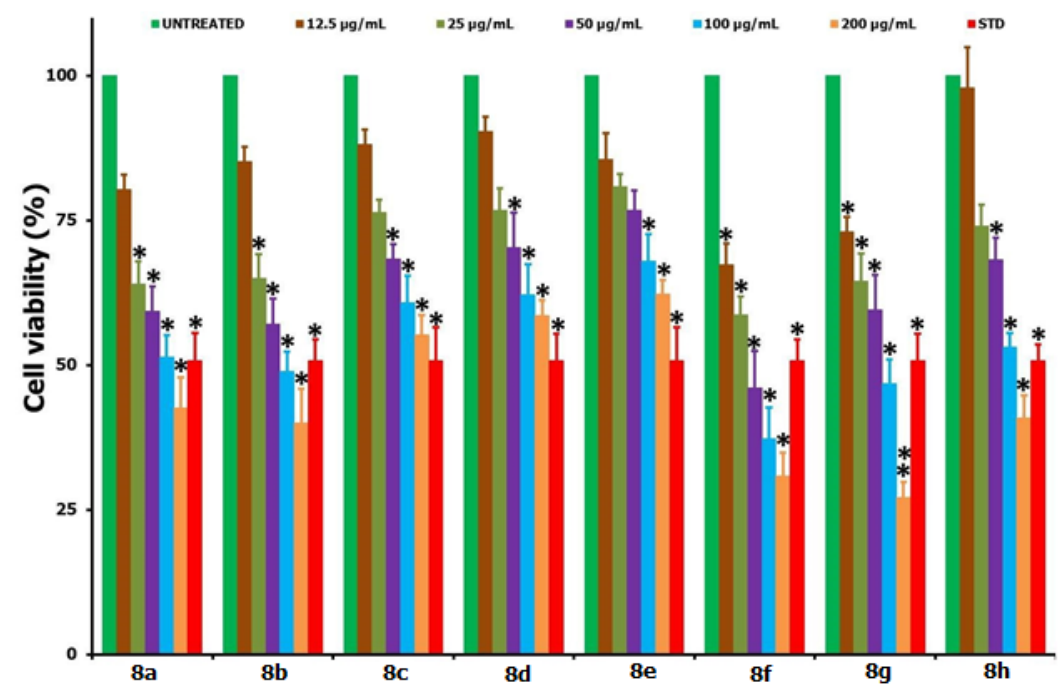

Figure 2. Comparison of cell viability results in vitro from the MTT assay against the HepG2 cells when treated with the tested compounds $8(\mathbf{a}-\mathbf{h})$ with a range of concentrations $(12.5-200 \mu \mathrm{g} / \mathrm{mL} ; 24 \mathrm{~h}$ period). From the figure, Standard (STD) stands for melphalan $(15 \mu \mathrm{g} / \mathrm{mL})$; ${ }^{*}$ and ${ }^{* *}$ relate to the significant $(p<0.05)$ and highly significant $(p<0.01)$ values as compared against those obtained with the untreated measurements. 


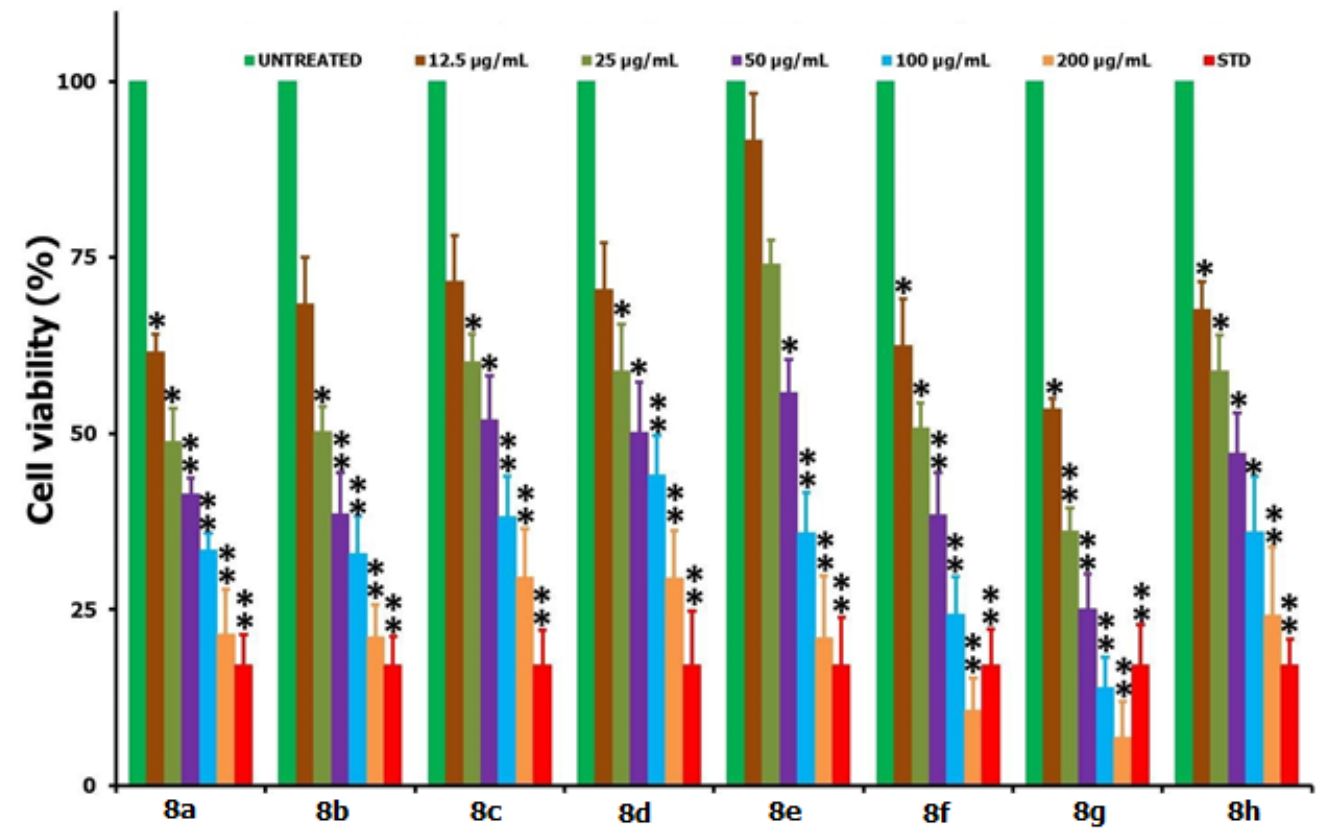

Figure 3. Cell viability comparison of MTT assay results of HepG2 cells from the treatment of compounds $8(\mathbf{a}-\mathbf{h})$ over a range of concentration $(12.5-200 \mu \mathrm{g} / \mathrm{mL} ; 48 \mathrm{~h}$ period). From the figure, STD stands for melphalan $(15 \mu \mathrm{g} / \mathrm{mL}) ;{ }^{*}$ and ${ }^{* *}$ relate to the significant $(p<0.05)$ and highly significant $(p<0.01)$ values as compared to those obtained with the untreated measurements.

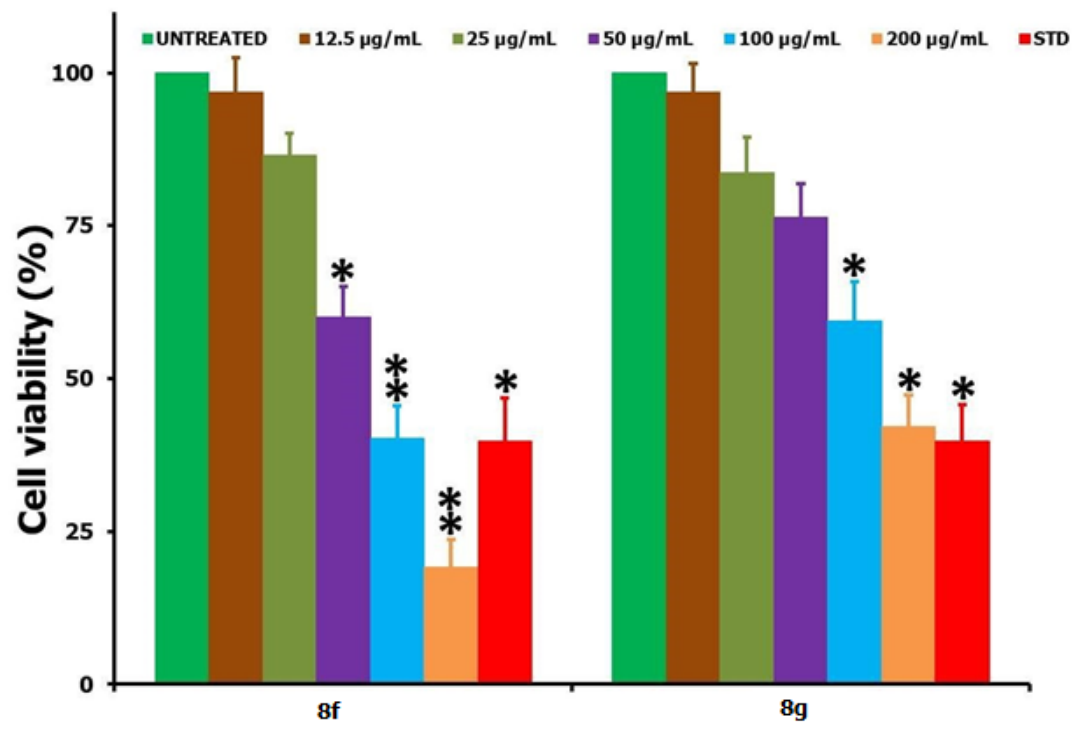

Figure 4. Comparison of MTT assay results of L929 noncancer cells following the incubation of two compounds $\mathbf{8 f}$ and $\mathbf{8 g}$ with a range of concentrations $(12.5-200 \mu \mathrm{g} / \mathrm{mL})$ over a $48 \mathrm{~h}$ period. STD stands for melphalan of $15 \mu \mathrm{g} / \mathrm{mL}^{*}$ and ${ }^{* *}$ refer to the significant $(p<0.05)$ and highly significant $(p<0.01)$ values as compared to those obtained with the untreated controls. 
Table 1. Comparison of the concentration required for $50 \%$ of cell death $\left(\mathrm{IC}_{50}\right)$ of the tested compounds $\mathbf{8}(\mathbf{a}-\mathbf{h})$ following the treatments to the HepG2 and L929 cells over 24 and $48 \mathrm{~h}$ incubation periods.

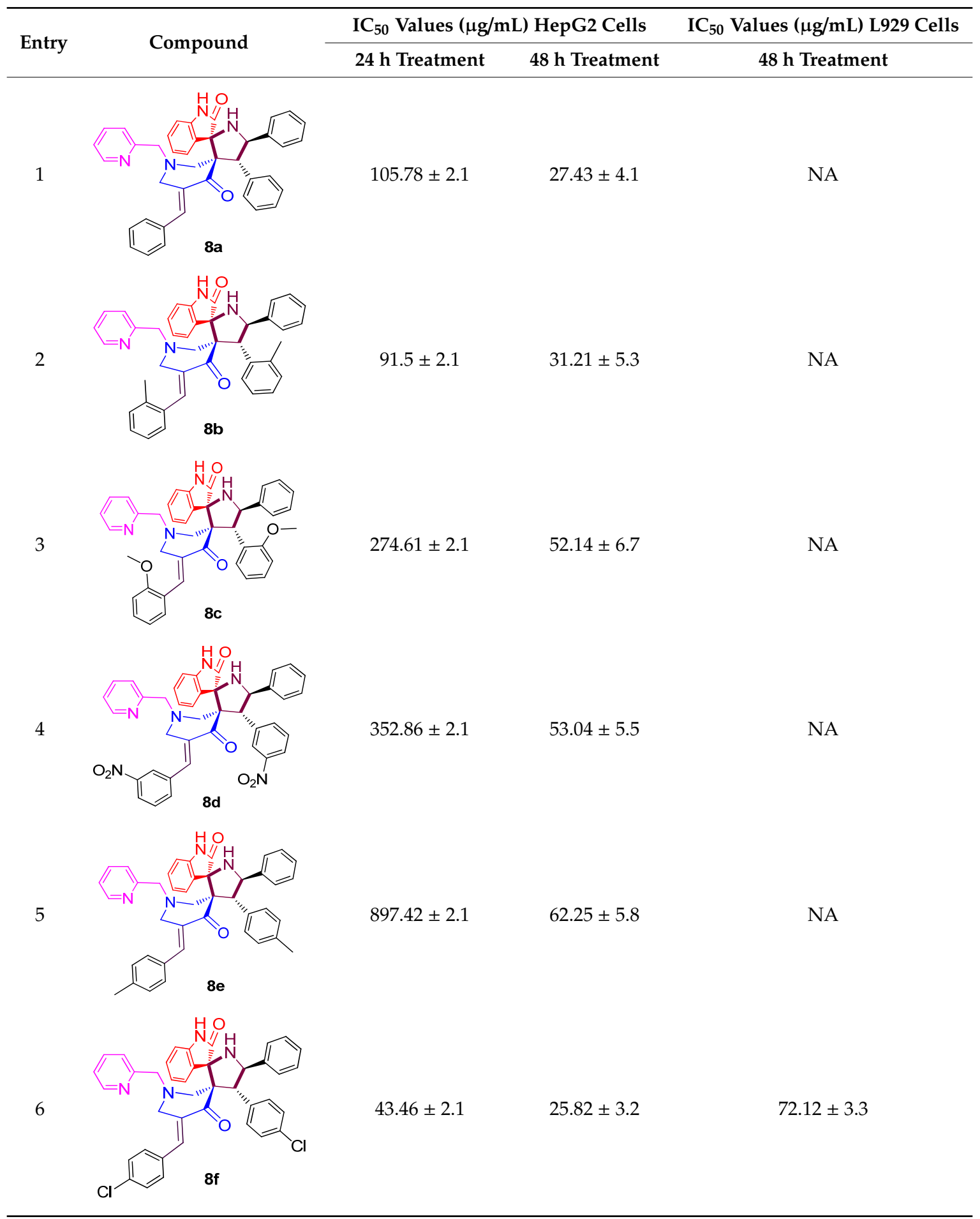


Table 1. Cont.

\begin{tabular}{|c|c|c|c|c|}
\hline \multirow{2}{*}{ Entry } & \multirow{2}{*}{ Compound } & \multicolumn{2}{|c|}{ IC $_{50}$ Values $(\mu \mathrm{g} / \mathrm{mL})$ HepG2 Cells } & \multirow{2}{*}{$\frac{\text { IC }_{50} \text { Values }(\mu \mathrm{g} / \mathrm{mL}) \text { L929 Cells }}{48 \mathrm{~h} \text { Treatment }}$} \\
\hline & & $24 \mathrm{~h}$ Treatment & $48 \mathrm{~h}$ Treatment & \\
\hline 7 & & $65.18 \pm 2.1$ & $12.79 \pm 2.6$ & $153.89 \pm 4.2$ \\
\hline 8 & & $120.76 \pm 2.1$ & $41.32 \pm 3.2$ & NA \\
\hline
\end{tabular}

To understand the cell death mechanism followed by the treatment of compound $8 \mathrm{~g}$, the apoptosis, reactive oxygen species (ROS), and caspase activity assays were performed, and the obtained results were compared with those of the positive control (melphalan; $15 \mu \mathrm{g} / \mathrm{mL}$ ) and the negative control of the cells without any treatment. Figure 5 shows the flow cytometry provided apoptosis assay results of the HepG2 cells due the treatment of the compound $8 \mathrm{~g}$ (at $\mathrm{IC}_{50}$ concentration.) and the positive control (melphalan) and the negative control of the cells (no treatment). The results of A-2, B-2, and C-2 provided in Figure 5 represented the mixed fluorescence intensities from the cells treated with propidium iodide (PI), and Annexin V-fluorescein isothiocyanate (Annexin V-FITC), the cells treated with the compound $\mathbf{8 g}$, and melphalan-treated cells, respectively. From the compound $\mathbf{8 g}$-treated cells, we observed that about $66.5 \%$ cells were live, $10 \%$ were apoptotic, and $17.5 \%$ were late apoptotic/early necrotic (Figure 5(B-2)); these values were far better than those of the melphalan-treated cells where we observed only $17.4 \%$ of live cells, $2.2 \%$ of apoptotic, and $46 \%$ of late apoptotic/early necrotic cells (Figure 5(C-2)). In addition, M1 and M2 shown in Figure 5 (A-3), 5(B-3), and 5(C-3) corresponded to the fluorescence intensities generated from the Annexin V-FITC dye by the viable and apoptotically dying cells, respectively. We observed from the Figure 5 that about $31.7 \%$ of the compound 8 g-treated cells were apoptotic and $68.7 \%$ of these cells were live. However, $65.2 \%$ of the melphalan-treated cells were apoptotic, and $35.6 \%$ of those cells were live. Thus, from the analysis of fluorescence intensity results by the PI and Annexin V-FITC, it can be indicated that apoptosis is the dominating mechanism for the observed loss of cell viability in the case of the HepG2 cancer cells.

Figure 6 shows the flow cytometric analysis towards the measurement of ROS generated following the treatment of the compound $8 \mathrm{~g}$ (at $\mathrm{IC}_{50}$ conc.) to the HepG2 cells when compared with those of the positive control (melphalan) and the negative control (cells of no treatment). From the analysis of results, it can be observed that about $97 \%$ of apoptotic cells generated the ROS in the case of the compound $8 \mathrm{~g}$ treated cells (Figure 6 (B-3)) and this value was far higher than that of the positive control (melphalan)-treated cells (only 13.6\% cells were apoptotic cells; Figure 6 (C-3)). The observation of such a high value of ROS generation from the compound 8g-treated cells indicated that most of the apoptotic cells released the ROS during their contact with the tested compound. 

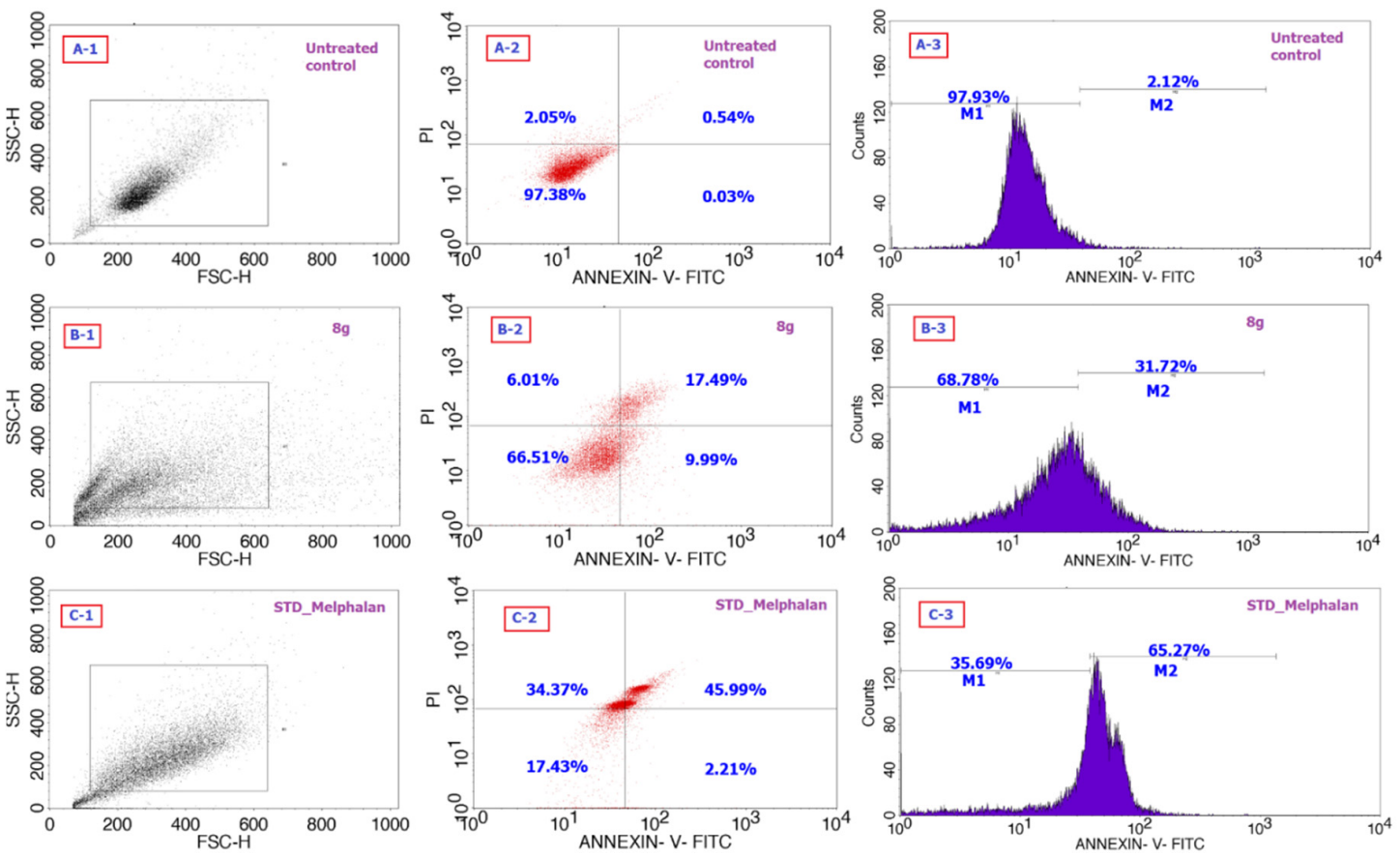

Figure 5. Apoptosis assay comparison of the fluorescence assay results following the treatment of HepG2 cells with that of the tested compound $8 \mathrm{~g}$ (B). The results were compared with those of melphalan used as the positive control (C) and no cell treatment used as the negative control (A) over a $48 \mathrm{~h}$ period.
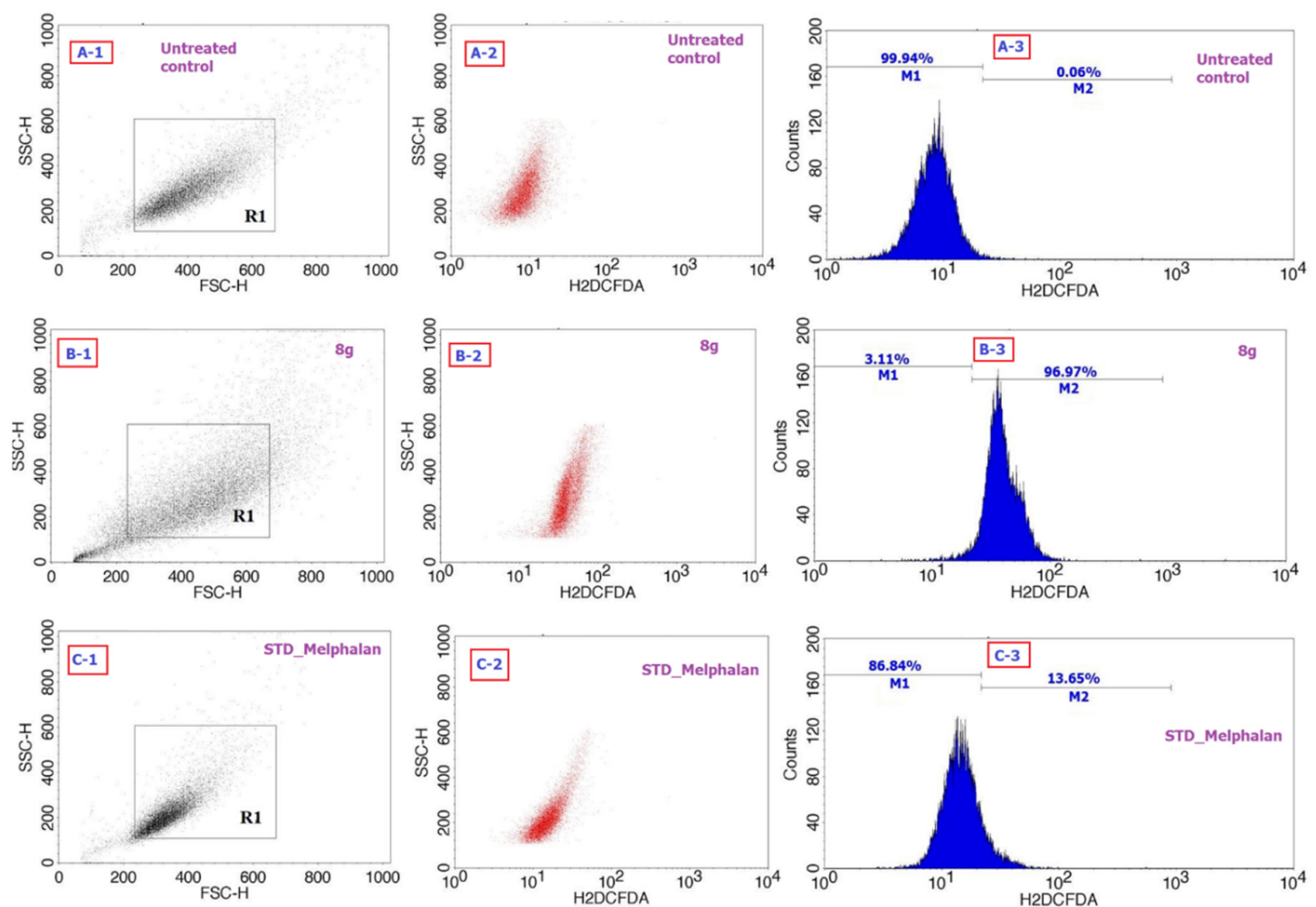

Figure 6. Reactive oxygen species (ROS) generation as a measure of fluorescence intensity in the HepG2 cells following the negative control having no cell treatment (A), the treatment of compound $8 \mathbf{g}(\mathbf{B})$, and the positive control melphalan (C) over a $48 \mathrm{~h}$ period. 
The involvement of caspases by means of caspase-3 activity was tested for the HepG2 cancer cells due to the treatment of the compound $8 \mathrm{~g}$ (at $\mathrm{IC}_{50}$ conc.), where the results were compared against the untreated and melphalan-treated controls as shown in Figure 7 . We observed a very high number of fluorescent cells from the tested compound 8g-treated cells (Figure 7c) as against those from the positive control (Figure $7 \mathrm{~b}$ ) and the negative control (Figure 7a), and the same trend was quantitatively shown in Figure 7d. This indicated that the HepG2 cells underwent the caspase-3 release before they lost the viability, thereby confirming for the involvement of caspases for the compound 8g-treated cells.
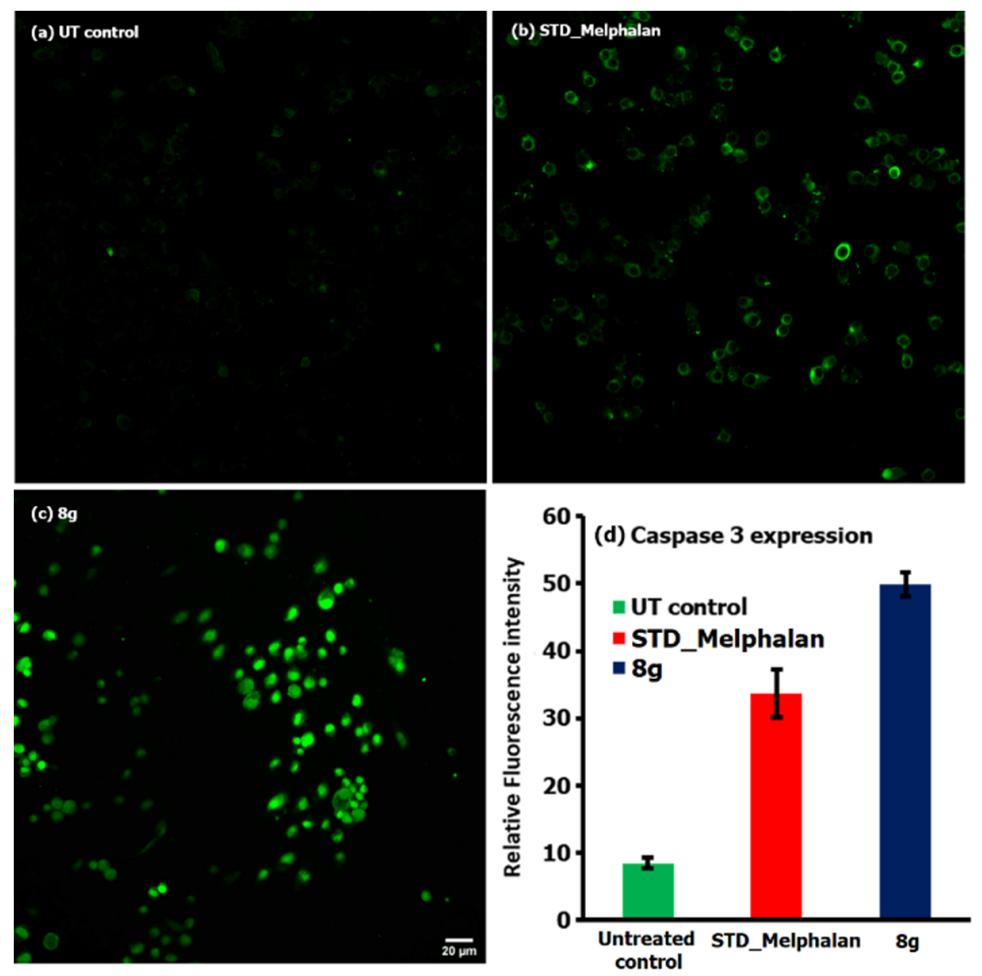

Figure 7. Comparison of caspase-3 activity results provided by the co-incubation of HepG2 cells with the negative control having no cell treatment (a), treated with melphalan used as the positive control (b), and treated with the compound $8 \mathrm{~g}$ (c) over a $48 \mathrm{~h}$ period. The relative fluorescence intensities of all the treatments were compared in (d).

\section{Materials and Methods}

The detailed materials and methods were provided in Supplementary Materials.

3.1. 4-(aryl)-5-phenylpyrrolo(spiro[2.3"]-oxindole)-spiro[3.3']-5'-(2-arylmethylidene)-1'-N(pyridinylmethyl)piperidin-4'-one $8(\boldsymbol{a}-\boldsymbol{h})$

An equimolar mixture of $N$-substituted bisarylmethylidene-tetrahydropyridinones $\mathbf{5}(\mathbf{a}-\mathbf{h})(0.100 \mathrm{~g}$, $0.27 \mathrm{mmol})$, isatin $6(0.040 \mathrm{~g}, 0.27 \mathrm{mmol})$, and phenylglycine $7(0.041 \mathrm{~g}, 0.27 \mathrm{mmol})$ were dissolved in methanol $(5 \mathrm{~mL})$ and heated under reflux with constant stirring for $4 \mathrm{~h}$. After completing the reaction as evident from TLC, the reaction mixture was transferred into $50 \mathrm{~mL}$ of ice-cold water to form a precipitate which was separated out by filtration and washed with water to obtain the product $8(\mathbf{a}-\mathbf{h})$ in good yields.

3.2. 4,5-Diphenylpyrrolo(spiro[2.3"]-oxindole)-spiro-[3.3']-5'-(phenylmethylidene)-1'-N(pyridinylmethyl)piperidin-4'-one $(8 a)$

Obtained as a white solid (88\%); $\mathrm{mp}=219-22{ }^{\circ} \mathrm{C}$; IR (KBr): 2359, 2340, 1698, and $1599 \mathrm{~cm}^{-1}$; ${ }^{1} \mathrm{H} \mathrm{NMR}\left(500 \mathrm{MHz}, \mathrm{CDCl}_{3}\right): \delta_{\mathrm{H}} 2.11\left(\mathrm{~d}, 1 \mathrm{H}, J=12.5 \mathrm{~Hz}, 2^{\prime}-\mathrm{CH}_{2}\right), 2.51(\mathrm{brs}, \mathrm{NH}), 2.96(\mathrm{dd}, 1 \mathrm{H}, J=15.0$, 
$\left.2.5 \mathrm{~Hz}, 6^{\prime}-\mathrm{CH}_{2}\right), 3.35\left(\mathrm{~d}, 1 \mathrm{H}, J=14.0 \mathrm{~Hz}, 7^{\prime}-\mathrm{CH}_{2}\right), 3.42\left(\mathrm{~d}, 1 \mathrm{H}, J=14.5 \mathrm{~Hz}, 6^{\prime}-\mathrm{CH}_{2}\right), 3.65(\mathrm{dd}, 1 \mathrm{H}$, $\left.J=13.0,2.0 \mathrm{~Hz}, 2^{\prime}-\mathrm{CH}_{2}\right), 3.76\left(\mathrm{~d}, 1 \mathrm{H}, J=13.5 \mathrm{~Hz}, 7^{\prime}-\mathrm{CH}_{2}\right), 4.72(\mathrm{~d}, 1 \mathrm{H}, J=10.0 \mathrm{~Hz}, 4-\mathrm{CH}), 5.47(\mathrm{~d}, 1 \mathrm{H}$, $J=11.0 \mathrm{~Hz}, 5-\mathrm{CH}), 6.63(\mathrm{~d}, 1 \mathrm{H}, J=8.0 \mathrm{~Hz}, \mathrm{ArH}), 6.93-7.09(\mathrm{~m}, 7 \mathrm{H}, \mathrm{ArH}), 7.18-7.28(\mathrm{~m}, 9 \mathrm{H}, \mathrm{ArH})$, $7.43(\mathrm{~d}, 2 \mathrm{H}, J=7.5 \mathrm{~Hz}, \mathrm{ArH}), 7.47(\mathrm{dd}, 1 \mathrm{H}, J=7.5,2.0 \mathrm{~Hz}, \mathrm{ArH}), 7.54(\mathrm{~d}, 2 \mathrm{H}, J=7.5 \mathrm{~Hz}, \mathrm{ArH}), 8.26(\mathrm{~s}, 1 \mathrm{H}$, $\mathrm{NH}), 8.42-8.43(\mathrm{~m}, 1 \mathrm{H}, \mathrm{ArH}) .{ }^{13} \mathrm{C}$ NMR $\left(125 \mathrm{MHz}, \mathrm{CDCl}_{3}\right): \delta_{\mathrm{C}} 53.95,56.95,57.04,63.68,64.23,67.01$, $72.03,109.11,122.05,122.07,123.06,126.85,126.96,127.52,127.64,128.21,128.28,128.70,128.88,129.01$, 129.90, 130.00, 132.91, 134.82, 136.17, 137.31, 137.60, 140.80, 141.51, 148.94, 157.34, 180.53, and 199.33. Mass: $603\left[\mathrm{M}^{+}\right]$. Anal. calc. for $\mathrm{C}_{40} \mathrm{H}_{34} \mathrm{~N}_{4} \mathrm{O}_{2}: \mathrm{C}, 79.71 ; \mathrm{H}, 5.69 ; \mathrm{N}, 9.30$. Found: $\mathrm{C}, 79.85 ; \mathrm{H}, 5.51$; $\mathrm{N}, 9.44 \%$.

\subsection{4-(2-Methylphenyl)-5-phenylpyrrolo(spiro[2.3"]-oxindole)spiro[3.3']-5'-(2-methylphenyl-methylidene)-} $1^{\prime}-N$-(pyridinylmethyl)piperidin-4'-one (8b)

Obtained as a white solid (90\%); $\mathrm{mp}=190-193{ }^{\circ} \mathrm{C}$; IR (KBr): 2358, 2337, 1699, and $1597 \mathrm{~cm}^{-1}$; ${ }^{1} \mathrm{H}$ NMR $\left(500 \mathrm{MHz}, \mathrm{CDCl}_{3}\right): \delta_{\mathrm{H}} 2.10\left(\mathrm{~d}, 1 \mathrm{H}, J=13.0 \mathrm{~Hz}, 2^{\prime}-\mathrm{CH}_{2}\right), 2.11\left(\mathrm{~s}, 3 \mathrm{H}, \mathrm{CH}_{3}\right), 2.16\left(\mathrm{~s}, 3 \mathrm{H}, \mathrm{CH}_{3}\right)$, $2.90\left(\mathrm{dd}, 1 \mathrm{H}, J=15.0,3.0 \mathrm{~Hz}, 6^{\prime}-\mathrm{CH}_{2}\right), 3.24-3.28\left(\mathrm{~m}, 2 \mathrm{H}, 7^{\prime}-\mathrm{CH}_{2}, 6^{\prime}-\mathrm{CH}_{2}\right), 3.51(\mathrm{dd}, 1 \mathrm{H}, J=13.0,2.0$ $\left.\mathrm{Hz}, 2^{\prime}-\mathrm{CH}_{2}\right), 3.63\left(\mathrm{~d}, 1 \mathrm{H}, J=14.0 \mathrm{~Hz}, 7^{\prime}-\mathrm{CH}_{2}\right), 4.92(\mathrm{~d}, 1 \mathrm{H}, J=10.5 \mathrm{~Hz}, 4-\mathrm{CH}), 5.53(\mathrm{~d}, 1 \mathrm{H}, J=10.0 \mathrm{~Hz}$, 5-CH), 6.68-6.71 (m, 2H, ArH), $6.80(\mathrm{~d}, 1 \mathrm{H}, J=8.0 \mathrm{~Hz}, \mathrm{ArH}), 6.93-7.20(\mathrm{~m}, 6 \mathrm{H}, \mathrm{ArH}), 7.23-7.30(\mathrm{~m}, 8 \mathrm{H}$, $\mathrm{ArH}), 7.41-7.62(\mathrm{~m}, 4 \mathrm{H}, \mathrm{ArH}), 8.07(\mathrm{~s}, 1 \mathrm{H}, \mathrm{ArH}), 8.38-8.39(\mathrm{~m}, 1 \mathrm{H}, \mathrm{ArH}) .{ }^{13} \mathrm{C} \mathrm{NMR}\left(125 \mathrm{MHz}, \mathrm{CDCl}_{3}\right)$ : $\delta_{C} 20.13,21.19,54.04,54.64,58.52,64.38,65.11,66.11,73.81,109.34,122.07,122.50,122.60,125.56,125.98$, $126.70,127.05,127.53,128.25,128.45,128.52,128.83,128.89,129.56,130.21,130.28,132.53,134.01,136.16$, $136.39,137.45,137.94,141.50,141.89,149.06,157.73,179.23$, and 199.89. Mass: 631 [M+]. Anal. calc. for $\mathrm{C}_{42} \mathrm{H}_{38} \mathrm{~N}_{4} \mathrm{O}_{2}$ : C, 79.97; $\mathrm{H}, 6.07 ; \mathrm{N}, 8.88$. Found: $\mathrm{C}, 79.85 ; \mathrm{H}, 6.16 ; \mathrm{N}, 8.97 \%$.

\subsection{4-(2-Methoxyphenyl)-5-phenylpyrrolo(spiro[2.3"]-oxindole)spiro[3.3']-5'-(2-methoxy-} phenylmethylidene) $1^{\prime}-N$-(pyridinylmethyl)piperidin-4'-one (8c)

Obtained as a reddish brown solid $(86 \%) ; \mathrm{mp}=170-173{ }^{\circ} \mathrm{C}$; IR $(\mathrm{KBr}): 2359,2339,1697$, and $1598 \mathrm{~cm}^{-1} ;{ }^{1} \mathrm{H}$ NMR $\left(500 \mathrm{MHz}, \mathrm{CDCl}_{3}\right): \delta_{\mathrm{H}} 2.20\left(\mathrm{~d}, 1 \mathrm{H}, J=12.5 \mathrm{~Hz}, 2^{\prime}-\mathrm{CH}_{2}\right), 2.95(\mathrm{dd}, 1 \mathrm{H}$, $\left.J=15.0,3.0 \mathrm{~Hz}, 6^{\prime}-\mathrm{CH}_{2}\right), 3.26\left(\mathrm{~d}, 1 \mathrm{H}, J=13.5 \mathrm{~Hz}, 7^{\prime}-\mathrm{CH}_{2}\right), 3.34\left(\mathrm{dd}, 1 \mathrm{H}, J=15.0 \mathrm{~Hz}, 6^{\prime}-\mathrm{CH}_{2}\right), 3.47(\mathrm{~s}, 3 \mathrm{H}$, $\left.\mathrm{OCH}_{3}\right), 3.64\left(\mathrm{dd}, 1 \mathrm{H}, J=12.5,2.5 \mathrm{~Hz}, 2^{\prime}-\mathrm{CH}_{2}\right), 3.72\left(\mathrm{~s}, 3 \mathrm{H}, \mathrm{OCH}_{3}\right), 3.78\left(\mathrm{~d}, 1 \mathrm{H}, J=13.5 \mathrm{~Hz}, 7^{\prime}-\mathrm{CH}_{2}\right)$, $4.93(\mathrm{~d}, 1 \mathrm{H}, J=10.0 \mathrm{~Hz}, 4-\mathrm{CH}), 5.67(\mathrm{~d}, 1 \mathrm{H}, J=10.5 \mathrm{~Hz}, 5-\mathrm{CH}), 6.65-6.72(\mathrm{~m}, 2 \mathrm{H}, \mathrm{ArH}), 6.84(\mathrm{~d}, 1 \mathrm{H}$, $J=7.5 \mathrm{~Hz}, \mathrm{ArH}), 6.95-7.32(\mathrm{~m}, 16 \mathrm{H}, \mathrm{ArH}), 7.40-7.65(\mathrm{~m}, 4 \mathrm{H}, \mathrm{ArH}), 8.08(\mathrm{~s}, 1 \mathrm{H}, \mathrm{ArH}), 8.39-8.41(\mathrm{~m}, 1 \mathrm{H}$, ArH). ${ }^{13} \mathrm{C}$ NMR $\left(125 \mathrm{MHz}, \mathrm{CDCl}_{3}\right): \delta_{\mathrm{C}} 54.03,54.72,55.42,55.87,58.57,64.43,65.16,66.24,73.88,109.31$, $112.98,122.27,122.55,122.64,125.51,126.00,126.73,127.11,127.54,128.29,128.56,128.85,128.93,129.63$, 130.20, 130.38, 132.54, 13408, 136.33, 136.45, 137.41, 140.50, 141.76, 149.09, 157.70, 158.11, 160.98, 179.72, and 199.85. Mass: $663\left[\mathrm{M}^{+}\right]$. Anal. calc. for $\mathrm{C}_{42} \mathrm{H}_{38} \mathrm{~N}_{4} \mathrm{O}_{4}$ : C, 76.11; $\mathrm{H}, 5.78 ; \mathrm{N}, 8.45$. Found: $\mathrm{C}, 76.30$; $\mathrm{H}, 5.90 ; \mathrm{N}, 8.31 \%$.

3.5. 4-(3-Nitrophenyl)-5-phenylpyrrolo(spiro[2.3"]-oxindole)spiro[3.3']-5'-(3-nitrophenyl methylidene)-1'-N(pyridinylmethyl)piperidin-4'-one (8d)

Obtained as a white solid (87\%); $\mathrm{mp}=193-196{ }^{\circ} \mathrm{C}$; IR (KBr): 2358, 2336, 1698, $1597 \mathrm{~cm}^{-1} ;{ }^{1} \mathrm{H}$ NMR $\left(500 \mathrm{MHz}, \mathrm{CDCl}_{3}\right): \delta_{\mathrm{H}} 1.99\left(\mathrm{~d}, 1 \mathrm{H}, J=13.0 \mathrm{~Hz}, 2^{\prime}-\mathrm{CH}_{2}\right), 2.99\left(\mathrm{dd}, 1 \mathrm{H}, J=15.0,2.5 \mathrm{~Hz}, 6^{\prime}-\mathrm{CH}_{2}\right)$, $3.34\left(\mathrm{~d}, 1 \mathrm{H}, J=15.0 \mathrm{~Hz}, 7^{\prime}-\mathrm{CH}_{2}\right), 3.40\left(\mathrm{~d}, 1 \mathrm{H}, J=15.0 \mathrm{~Hz}, 6^{\prime}-\mathrm{CH}_{2}\right), 3.70(\mathrm{dd}, 1 \mathrm{H}, J=13.0,3.0 \mathrm{~Hz}$, $\left.2^{\prime}-\mathrm{CH}_{2}\right), 3.77-3.92\left(\mathrm{~m}, 1 \mathrm{H}, 7^{\prime}-\mathrm{CH}_{2}\right), 4.77(\mathrm{~d}, 1 \mathrm{H}, J=10.5 \mathrm{~Hz}, 4-\mathrm{CH}), 5.49(\mathrm{~d}, 1 \mathrm{H}, J=11.0 \mathrm{~Hz}, 5-\mathrm{CH})$, $6.65(\mathrm{~d}, 1 \mathrm{H}, J=7.5 \mathrm{~Hz}, \mathrm{ArH}), 6.96-7.06(\mathrm{~m}, 1 \mathrm{H}, \mathrm{ArH}), 7.10-7.27(\mathrm{~m}, 11 \mathrm{H}, \mathrm{ArH}), 7.40-7.48(\mathrm{~m}, 1 \mathrm{H}, \mathrm{ArH})$, 7.52-7.82 (m, 6H, ArH), $8.05(\mathrm{~d}, 1 \mathrm{H}, J=8.0 \mathrm{~Hz}, \mathrm{ArH}), 8.20(\mathrm{~d}, 1 \mathrm{H}, J=8.0 \mathrm{~Hz}, \mathrm{ArH}), 8.24(\mathrm{~s}, 1 \mathrm{H}, \mathrm{NH})$, 8.48-8.50 (m, 1H, ArH). ${ }^{13} \mathrm{C}$ NMR $\left(125 \mathrm{MHz}, \mathrm{CDCl}_{3}\right): \delta_{\mathrm{C}} 54.41,56.21,56.48,63.29,64.32,67.10,71.51$, $109.51,122.58,122.66,123.29,126.92,127.03,127.68,128.20,128.43,128.65,129.43,129.77,130.28,132.62$, 134.21, 134.65, 135.35, 135.46, 136.16, 136.34, 136.61, 138.37, 139.42, 139.98, 140.09, 141.68, 148.09, 149.54, 156.49, 181.90, and 198.37. Mass: $693\left[\mathrm{M}^{+}\right]$. Anal. calc. for $\mathrm{C}_{40} \mathrm{H}_{32} \mathrm{~N}_{6} \mathrm{O}_{6}: \mathrm{C}, 69.35 ; \mathrm{H}, 4.66 ; \mathrm{N}, 12.13$. Found: C, 69.46; H, 4.74; N, 12.25\%. 
3.6. 4-(4-Methylphenyl)-5-phenylpyrrolo(spiro[2.3"]-oxindole)spiro[3.3']-5'-(4-methylphenyl-methylidene)$1^{\prime}-N$-(pyridinylmethyl)piperidin-4'-one $(8 \boldsymbol{e})$

Obtained as a white solid (90\%); mp = 195-198 ${ }^{\circ} \mathrm{C}$; IR (KBr): 2360, 2341, 1698, and $1597 \mathrm{~cm}^{-1}$; ${ }^{1} \mathrm{H} \mathrm{NMR}\left(500 \mathrm{MHz}, \mathrm{CDCl}_{3}\right): \delta_{\mathrm{H}} 2.13\left(\mathrm{~d}, 1 \mathrm{H}, J=13.0 \mathrm{~Hz}, 2^{\prime}-\mathrm{CH}_{2}\right), 2.26\left(\mathrm{~s}, 3 \mathrm{H}, \mathrm{CH}_{3}\right), 2.27\left(\mathrm{~s}, 3 \mathrm{H}, \mathrm{CH}_{3}\right)$, $2.97\left(\mathrm{dd}, 1 \mathrm{H}, \mathrm{J}=15.0,3.0 \mathrm{~Hz}, 6^{\prime}-\mathrm{CH}_{2}\right), 3.37\left(\mathrm{~d}, 1 \mathrm{H}, J=13.5 \mathrm{~Hz}, 7^{\prime}-\mathrm{CH}_{2}\right), 3.42(\mathrm{~d}, 1 \mathrm{H}, J=15.0 \mathrm{~Hz}$, $\left.6^{\prime}-\mathrm{CH}_{2}\right), 3.63\left(\mathrm{dd}, 1 \mathrm{H}, J=13.0,2.5 \mathrm{~Hz}, 2^{\prime}-\mathrm{CH}_{2}\right), 3.79\left(\mathrm{~d}, 1 \mathrm{H}, J=13.5 \mathrm{~Hz}, 7^{\prime}-\mathrm{CH}_{2}\right), 4.68(\mathrm{~d}, 1 \mathrm{H}, J=11.0 \mathrm{~Hz}$, 4-CH), $5.43(\mathrm{~d}, 1 \mathrm{H}, J=11.0 \mathrm{~Hz}, 5-\mathrm{CH}), 6.62(\mathrm{~d}, 1 \mathrm{H}, J=7.5 \mathrm{~Hz}, \mathrm{ArH}), 6.87(\mathrm{~d}, 2 \mathrm{H}, J=8.5 \mathrm{~Hz}, \mathrm{ArH})$, 6.91-7.10 (m, 9H, ArH), 7.15-7.19 (m, 1H, ArH), 7.20-7.26 (m, 3H, ArH), 7.31 (d, 2H, J = 8.0 Hz, ArH), 7.46-7.50 (m, 1H, ArH), 7.53-7.55 (m, 2H, ArH), 8.11 (s, 1H, NH), 8.44-8.45 (m, 1H, ArH). ${ }^{13} \mathrm{C} \mathrm{NMR}$ $\left(125 \mathrm{MHz}, \mathrm{CDCl}_{3}\right): \delta_{\mathrm{C}} 21.07,21.30,54.21,56.81,57.03,63.90,64.36,66.87,72.17,109.04,122.03,122.05$, $123.05,126.94,127.46,127.68,128.27,128.80,128.95,129.02,129.08,129.74,130.27,131.97,132.06,134.22$, 136.20, 136.30, 137.73, 139.14, 140.94, 141.47, 148.97, 157.54, 180.42, 199.35. Mass: 631 [M ${ }^{+}$]. Anal. calc. for $\mathrm{C}_{42} \mathrm{H}_{38} \mathrm{~N}_{4} \mathrm{O}_{2}$ : C, 79.97; $\mathrm{H}, 6.07 ; \mathrm{N}, 8.88$. Found: $\mathrm{C}, 79.81 ; \mathrm{H}, 6.21 ; \mathrm{N}, 8.75 \%$.

3.7. 4-(4-Chlorophenyl)-5-phenylpyrrolo(spiro[2.3"]-oxindole)spiro[3.3']-5'-(4-chlorophenyl-methylidene)-1'$\mathrm{N}$-(pyridinylmethyl)piperidin- $4^{\prime}$-one $(8 f)$

Obtained as a white solid (87\%); $\mathrm{mp}=198-202{ }^{\circ} \mathrm{C}$; IR $(\mathrm{KBr}): 2359,2340,1698$, and $1597 \mathrm{~cm}^{-1}$; ${ }^{1} \mathrm{H}$ NMR $\left(500 \mathrm{MHz}, \mathrm{CDCl}_{3}\right): \delta_{\mathrm{H}} 2.06\left(\mathrm{~d}, 1 \mathrm{H}, J=12.5 \mathrm{~Hz}, 2^{\prime}-\mathrm{CH}_{2}\right), 2.95\left(\mathrm{dd}, 1 \mathrm{H}, J=15.0,3.0 \mathrm{~Hz}, 6^{\prime}-\mathrm{CH}_{2}\right)$, 3.34-3.40 (m, 2H, $\left.7^{\prime}-\mathrm{CH}_{2}, 6^{\prime}-\mathrm{CH}_{2}\right), 3.62\left(\mathrm{dd}, 1 \mathrm{H}, J=13.0,2.5 \mathrm{~Hz}, 2^{\prime}-\mathrm{CH}_{2}\right), 3.80(\mathrm{~d}, 1 \mathrm{H}, J=13.0 \mathrm{~Hz}$, $\left.7^{\prime}-\mathrm{CH}_{2}\right), 4.65(\mathrm{~d}, 1 \mathrm{H}, J=10.5 \mathrm{~Hz}, 4-\mathrm{CH}), 5.40(\mathrm{~d}, 1 \mathrm{H}, J=10.5 \mathrm{~Hz}, 5-\mathrm{CH}), 6.60(\mathrm{~d}, 1 \mathrm{H}, J=7.5 \mathrm{~Hz}$, ArH), $6.84(\mathrm{~d}, 2 \mathrm{H}, J=8.5 \mathrm{~Hz}, \mathrm{ArH}), 6.92-6.99(\mathrm{~m}, 2 \mathrm{H}, \mathrm{ArH}), 7.05-7.11$ (m, 2H, ArH), 7.16-7.28 (m, 9H, ArH), 7.35 (d, 1H, J = 8.0 Hz, ArH), 7.50-7.53 (m, 4H, ArH), 7.83 (s, 1H, NH), 8.47-8.48 (m, 1H, ArH). ${ }^{13} \mathrm{C}$ NMR $\left(125 \mathrm{MHz}, \mathrm{CDCl}_{3}\right): \delta_{\mathrm{C}} 53.88,56.23,56.93,63.70,64.36,67.00,71.90,109.23,122.14,122.38$, 123.26, 127.09, 127.68, 127.83, 128.48, 128.56, 128.63, 128.92, 129.09, 131.27, 132.84, 133.25, 133.34, 134.92, 135.86, 136.33, 136.38, 140.54, 141.55, 149.29, 157.21, 180.40, and 198.97. Mass: 671 [M ${ }^{+}$]. Anal. calc. for $\mathrm{C}_{40} \mathrm{H}_{32} \mathrm{Cl}_{2} \mathrm{~N}_{4} \mathrm{O}_{2}$ : C, 71.53; $\mathrm{H}, 4.80 ; \mathrm{N}, 8.34$. Found: $\mathrm{C}, 71.74 ; \mathrm{H}, 4.91 ; \mathrm{N}, 8.25 \%$.

3.8. 4-(4-Fluorophenyl)-5-phenylpyrrolo(spiro[2.3"]-oxindole)spiro[3.3']-5'-(4-fluorophenyl-methylidene)-1'$N$-(pyridinylmethyl)piperidin- $4^{\prime}$-one $(8 g)$

Obtained as a white solid $(85 \%) ; \mathrm{mp}=164-166{ }^{\circ} \mathrm{C}$; IR $(\mathrm{KBr}): 2360,2337,1698$, and $1597 \mathrm{~cm}^{-1}$; ${ }^{1} \mathrm{H}$ NMR $\left(500 \mathrm{MHz}, \mathrm{CDCl}_{3}\right): \delta_{\mathrm{H}} 2.07\left(\mathrm{~d}, 1 \mathrm{H}, J=12.0 \mathrm{~Hz}, 2^{\prime}-\mathrm{CH}_{2}\right), 2.98\left(\mathrm{~d}, 1 \mathrm{H}, J=15.0 \mathrm{~Hz}, 6^{\prime}-\mathrm{CH}_{2}\right)$, 3.32-3.34 (m, 2H, $\left.7^{\prime}-\mathrm{CH}_{2}, 6^{\prime}-\mathrm{CH}_{2}\right), 3.60\left(\mathrm{dd}, 1 \mathrm{H}, J=15.0,5.0 \mathrm{~Hz}, 2^{\prime}-\mathrm{CH}_{2}\right), 3.80(\mathrm{~d}, 1 \mathrm{H}, J=12.5 \mathrm{~Hz}$, $\left.7^{\prime}-\mathrm{CH}_{2}\right), 4.66(\mathrm{~d}, 1 \mathrm{H}, J=10.0 \mathrm{~Hz}, 4-\mathrm{CH}), 5.39(\mathrm{~d}, 1 \mathrm{H}, J=11.0 \mathrm{~Hz}, 5-\mathrm{CH}), 6.61(\mathrm{~d}, 1 \mathrm{H}, J=7.0 \mathrm{~Hz}, \mathrm{ArH})$, 6.88-7.10 (m, 9H, ArH), 7.20-7.41 (m, 7H, ArH), 7.50-7.53 (m, 3H, ArH), 7.75 (s, 1H, NH), 8.44-8.48 (m, 1H, ArH). ${ }^{13} \mathrm{C}$ NMR $\left(125 \mathrm{MHz}, \mathrm{CDCl}_{3}\right): \delta_{\mathrm{C}} 54.06,56.99,57.08,63.94,64.31,66.82,72.10,109.11$, 115.17, 115.35, 122.09, 122.25, 123.07, 126.91, 127.45, 128.31, 128.94, 129.73, 130.28, 131.94, 132.16, 134.26, 136.24, 136.39, 137.71, 140.91, 141.48, 148.93, 157.55, 158.24, 160.17, 180.39, and 199.28. Mass: 631 [M $\left.{ }^{+}\right]$. Anal. calc. for $\mathrm{C}_{40} \mathrm{H}_{32} \mathrm{~F}_{2} \mathrm{~N}_{4} \mathrm{O}_{2}$ : C, 75.22; $\mathrm{H}, 5.05 ; \mathrm{N}, 8.77$. Found: $\mathrm{C}, 75.38 ; \mathrm{H}, 5.21 ; \mathrm{N}, 8.65 \%$.

3.9. 4-(2,4-Dichlorophenyl)-5-phenylpyrrolo(spiro[2.3"]-oxindole)spiro[3.3']-5'-(2,4-dichlorophenylmethylidene)-1'-N-(pyridinylmethyl)piperidin-4'-one (8h)

Obtained as a yellow solid (89\%); $\mathrm{mp}=125-128^{\circ} \mathrm{C}$; IR (KBr): 2359, 2340, 1699, and $1595 \mathrm{~cm}^{-1}$; ${ }^{1} \mathrm{H}$ NMR $\left(500 \mathrm{MHz}, \mathrm{CDCl}_{3}\right): \delta_{\mathrm{H}} 2.21\left(\mathrm{~d}, 1 \mathrm{H}, J=13.0 \mathrm{~Hz}, 2^{\prime}-\mathrm{CH}_{2}\right), 2.98\left(\mathrm{~d}, 1 \mathrm{H}, J=14.5 \mathrm{~Hz}^{\prime} 6^{\prime}-\mathrm{CH}_{2}\right)$, $3.21\left(\mathrm{~d}, 1 \mathrm{H}, J=14.0 \mathrm{~Hz}, 7^{\prime}-\mathrm{CH}_{2}\right), 3.29\left(\mathrm{~d}, 1 \mathrm{H}, J=14.5 \mathrm{~Hz}, 6^{\prime}-\mathrm{CH}_{2}\right), 3.61\left(\mathrm{~d}, 1 \mathrm{H}, J=14.0 \mathrm{~Hz}, 2^{\prime}-\mathrm{CH}_{2}\right)$, 3.71-3.76 (m, 1H, $\left.7^{\prime}-\mathrm{CH}_{2}\right), 5.07(\mathrm{~d}, 1 \mathrm{H}, J=9.5 \mathrm{~Hz}, 4-\mathrm{CH}), 5.52(\mathrm{~d}, 1 \mathrm{H}, J=9.5 \mathrm{~Hz}, 5-\mathrm{CH}), 6.70(\mathrm{t}, 1 \mathrm{H}$, $J=7.5 \mathrm{~Hz}, \mathrm{ArH}), 6.76(\mathrm{~d}, 1 \mathrm{H}, J=8.0 \mathrm{~Hz}, \mathrm{ArH}), 6.93-7.34(\mathrm{~m}, 11 \mathrm{H}, \mathrm{ArH}), 7.41-7.48(\mathrm{~m}, 3 \mathrm{H}, \mathrm{ArH})$, $7.60(\mathrm{~d}, 1 \mathrm{H}, \mathrm{J}=7.5 \mathrm{~Hz}, \mathrm{ArH}), 7.74(\mathrm{~s}, 1 \mathrm{H}, \mathrm{NH}), 7.88(\mathrm{~m}, 1 \mathrm{H}, \mathrm{ArH}), 8.10(\mathrm{~d}, 1 \mathrm{H}, \mathrm{J}=8.5 \mathrm{~Hz}, \mathrm{ArH}), 8.41-8.42$ $(\mathrm{m}, 1 \mathrm{H}, J=4.5 \mathrm{~Hz}, \mathrm{ArH}) .{ }^{13} \mathrm{C}$ NMR $\left(125 \mathrm{MHz} \mathrm{CDCl}_{3}\right): \delta_{\mathrm{C}} 54.23,54.66,57.87,64.30,64.50,65.53,74.55$, 109.39 , 122.24, 122.43, 122.97, 126.83, 126.94, 127.34, 127.71, 128.04, 128.73, 128.98, 129.25, 129.83, 129.90, $130.00,130.49$, 130.98, 131.69, 133.27, 133.70, 134.10, 134.81, 135.99, 136.32, 140.45, 141.61, 149.16, 157.41, 
166.79, 178.05, and 198.82. Mass: $741\left[\mathrm{M}^{+}\right]$. Anal. calc. for $\mathrm{C}_{40} \mathrm{H}_{30} \mathrm{Cl}_{4} \mathrm{~N}_{4} \mathrm{O}_{2}$ : C, 64.88; $\mathrm{H}, 4.08 ; \mathrm{N}, 7.57$. Found: $\mathrm{C}, 64.79 ; \mathrm{H}, 4.21 ; \mathrm{N}, 7.42 \%$.

\section{Conclusions}

An efficient synthesis of a series of novel spirooxindole-pyrrolidine heterocyclic molecular scaffolds in good to excellent yields has been achieved using a one-pot three-component $(3+2)$ cycloaddition reaction of azomethine ylide generated in situ from isatin and phenylglycine with a new class of functionalized dipolarophiles. The structure of all the new compounds were elucidated by FT-IR, NMR spectroscopy and mass spectrometric data. The synthesized spirooxindole heterocyclic hybrids were tested to investigate the extent of anticancer activities against the HepG2 cancer cells in vitro (up to $200 \mu \mathrm{g} / \mathrm{mL} ; 24-48 \mathrm{~h}$ time period). The comparative analysis of the obtained results with those of the positive control of melphalan $(15 \mu \mathrm{g} / \mathrm{mL})$ and the negative control of no cell treatments showed that the highest activity was obtained for the compound $8 \mathrm{~g}$ over a $48 \mathrm{~h}$ period (i.e., obtained the least $\mathrm{IC}_{50}$ value of only $12.7 \mu \mathrm{g} / \mathrm{mL}$ ). From the further investigation of the mechanism of toxicology, we found that the HepG2 cells experienced the apoptotic pathway with the induction of ROS generation and the involvement of caspases. This type of cell death mechanism is a potential pathway for the treatment of cancer cells, as noncancer cells do not have to scarify and full control over diseased cells can be possible.

Supplementary Materials: The following are available online. Detailed methodology, NMR, IR and mass spectra of a representative compound.

Author Contributions: Conceptualization, R.S.K.; investigation, D.M.A.-t., R.S.K., A.I.A., N.A., and F.M.; writing of the original draft preparation, R.S.K. and F.M.; supervision, R.S.K.; funding acquisition, A.I.A. All authors have read and agreed to the published version of the manuscript.

Funding: The authors acknowledge the Deanship of Scientific Research, King Saud University, Riyadh, Saudi Arabia for funding this work through the grant number RGP-026.

Acknowledgments: The authors thank Stellixir Biotech Pvt. Ltd., Bangalore, India for performing the biological assays.

Conflicts of Interest: There are no conflict to declare.

\section{References}

1. Irigaray, P.; Belpomme, D. Basic properties and molecular mechanisms of exogenous chemical carcinogens. Carcinog. 2009, 31, 135-148.

2. Gupta, A.; Kumar, B.S.; Negi, A.S. Current status on development of steroids as anticancer agents. J. Steroid Biochem. Mol. Biol. 2013, 137, 242-270. [PubMed]

3. Choi, S.K. Synthetic Multivalent Molecules: Concepts and Biomedical Applications; John Wiley \& Sons: New York City, NY, USA, 1807.

4. Nakagawa-Goto, K.; Nakamura, S.; Bastow, K.F.; Nyarko, A.K.; Peng, C.-Y.; Lee, F.-Y.; Lee, K.-H.; Lee, F.-C. Antitumor agents. 256. Conjugation of paclitaxel with other antitumor agents: Evaluation of novel conjugates as cytotoxic agents. Bioorg. Med. Chem. Lett. 2007, 17, 2894-2898. [PubMed]

5. Mohammadi, M.R.; Nojoomi, A.; Mozafari, M.; Dubnika, A.; Inayathullah, M.; Rajadas, J. Nanomaterials engineering for drug delivery: a hybridization approach. J. Mater. Chem. B 2017, 5, 3995-4018.

6. Tatsuzaki, J.; Taniguchi, M.; Bastow, K.F.; Nakagawa-Goto, K.; Morris-Natschke, S.L.; Itokawa, H.; Baba, K.; Lee, K.H. Antitumor Agents 255: Novel Glycyrrhetinic Acid-Dehydrozingerone Conjugates as Cytotoxic Agents. Bioorg. Med. Chem. 2007, 15, 6193-6199.

7. Nakagawa-Goto, K.; Yamada, K.; Nakamura, S.; Chen, T.-H.; Chiang, P.-C.; Bastow, K.F.; Wang, S.C.; Spohn, B.; Hung, M.C.; Lee, F.Y.; et al. Antitumor agents. 258. Syntheses and evaluation of dietary antioxidant - taxoid conjugates as novel cytotoxic agents. Bioorg. Med. Chem. Lett. 2007, 17, 5204-5209.

8. Shi, B.; Zhang, Z.; Jin, Q.; Wang, Z.; Tang, J.; Xu, G.; Zhu, T.; Gong, X.-Q.; Tang, X.; Zhao, C. Selective tracking of ovarian-cancer-specific $\gamma$-glutamyltranspeptidase using a ratiometric two-photon fluorescent probe. J. Mater. Chem. B 2018, 6, 7439-7443. 
9. Samala, G.; Devi, P.B.; Nallangi, R.; Sridevi, J.P.; Saxena, S.; Yogeeswari, P.; Sriram, D. Development of novel tetrahydrothieno[2-c]pyridine-3-carboxamide based Mycobacterium tuberculosis pantothenate synthetase inhibitors: Molecular hybridization from known antimycobacterial leads. Bioorg. Med. Chem. 2014, 22, 1938-1947.

10. Sang, Z.; Li, Y.; Qiang, X.; Xiao, G.; Liu, Q.; Tan, Z.; Deng, Y. Multifunctional scutellarin-rivastigmine hybrids with cholinergic, antioxidant, biometal chelating and neuroprotective properties for the treatment of Alzheimer's disease. Bioorg. Med. Chem. 2015, 23, 668-680.

11. Kamiński, K.; Rapacz, A.; Łuszczki, J.J.; Latacz, G.; Obniska, J.; Kieć-Kononowicz, K.; Filipek, B. Design, synthesis and biological evaluation of new hybrid anticonvulsants derived from N-benzyl-2-(2,5-dioxopyrrolidin-1-yl)propanamide and 2-(2,5-dioxopyrrolidin-1-yl)butanamide derivatives. Bioorg. Med. Chem. 2015, 23, 2548-2561.

12. Yang, X.; Qian, Y. A NIR facile, cell-compatible fluorescent sensor for glutathione based on Michael addition induced cascade spirolactam opening and its application in hepatocellular carcinoma. J. Mater. Chem. B 2018, 6, 7486-7494.

13. Liang, C.; Zhang, X.; Wang, Z.; Wang, W.; Yang, M.-S.; Dong, X. Organic/inorganic nanohybrids rejuvenate photodynamic cancer therapy. J. Mater. Chem. B 2020, 8, 4748-4763.

14. Wan, Z.-Y.; Tao, Y.; Wang, Y.-F.; Mao, T.-Q.; Yin, H.; Chen, F.-E.; Piao, H.-R.; Clercq, E.D.; Daelemans, D.; Pannecouque, C. Hybrid chemistry. Part 4: Discovery of etravirine-VRX-480773 hybrids as potent HIV-1 non-nucleoside reverse transcriptase inhibitors. Bioorg. Med. Chem. 2015, 23, 4248-4255.

15. Zhao, Y.; Su, J.; Goto, M.; Morris-Natschke, S.L.; Li, Y.; Zhao, Q.-S.; Yao, Z.-J.; Lee, K.-H. Dual-Functional abeo-Taxane Derivatives Destabilizing Microtubule Equilibrium and Inhibiting NF- $\mathrm{kB}$ Activation. J. Med. Chem. 2013, 56, 4749-4757.

16. Zhang, Y.; Wei, B.-W.; Lin, H.; Zhang, L.; Liu, J.-X.; Luo, H.-Q.; Fan, X.-L. “On water” direct catalytic vinylogous Henry (nitroaldol) reactions of isatins for the efficient synthesis of isoxazole substituted 3-hydroxyindolin-2-ones. Green Chem. 2015, 17, 3266-3270.

17. AlSalhi, M.S.; Elangovan, K.; Ranjitsingh, A.J.A.; Murali, P.; Devanesan, S. Synthesis of silver nanoparticles using plant derived 4-N-methyl benzoic acid and evaluation of antimicrobial, antioxidant and antitumor activity. Saudi J. Biol. Sci. 2019, 26, 970-978.

18. Devanesan, S.; Ponmurugan, K.; AlSalhi, M.S.; Dhabi, N.A.A. Cytotoxic and Antimicrobial Efficacy of Silver Nanoparticles Synthesized Using a Traditional Phytoproduct, Asafoetida Gum. Int. J. Nanomed. 2020, $15,4351-4362$.

19. MacLean, D.; Schullek, J.R.; Murphy, M.M.; Ni, Z.-J.; Gordon, E.M.; Gallop, M.A. Encoded combinatorial chemistry: Synthesis and screening of a library of highly functionalized pyrrolidines. Proc. Natl. Acad. Sci. USA 1997, 94, 2805-2810.

20. Hanessian, S.; Bayrakdarian, M. Pyrrolidine as a cogwheel-like scaffold for the deployment of diverse functionality through cycloaddition reactions of metallo-1,3-dipoles in aqueous media. Bioorganic Med. Chem. Lett. 2000, 10, 427-431.

21. Hanessian, S.; Bayrakdarian, M. Solution- and solid-phase asymmetric synthesis of substituted N-hydroxypyrrolidine dicarboxylic acids. Tetrahedron Lett. 2002, 43, 9441-9444.

22. Lo, M.M.-C.; Neumann, C.S.; Nagayama, S.; Perlstein, E.O.; Schreiber, S.L. A Library of Spirooxindoles Based on a Stereoselective Three-Component Coupling Reaction. J. Am. Chem. Soc. 2004, 126, 16077-16086. [CrossRef]

23. Han, W.-Y.; Zhao, J.-Q.; Zuo, J.; Xu, X.-Y.; Zhang, X.-M.; Yuan, W.-C. Recent Advances of $\alpha$-Isothiocyanato Compounds in the Catalytic Asymmetric Reaction. Adv. Synth. Catal. 2015, 357, 3007-3031. [CrossRef]

24. Zhou, J.; Yu, J.-S.; Zhou, F.; Liu, Y. A Journey in the Catalytic Synthesis of 3-Substituted 3-Aminooxindoles. Synlett 2015, 26, 2491-2504. [CrossRef]

25. Das, U.; Pati, H.N.; Sakagami, H.; Hashimoto, K.; Kawase, M.; Balzarini, J.; De Clercq, E.; Dimmock, J.R. 3,5-Bis(benzylidene)-1-[3-(2-hydroxyethylthio)propanoyl]piperidin-4-ones: A Novel Cluster of Potent Tumor-Selective Cytotoxins. J. Med. Chem. 2011, 54, 3445-3449. [CrossRef]

26. Dimmock, J.R.; Maniyan, P.P.; Ramanan, N.P.; Adil, J.N.; Narasimhan, L.M.; Gordon, A.Z.; Quail, J.W.; Oloo, E.O.; Kraatz, H.B.; Prisciak, J.S.; et al. A conformational and structure-activity relationship study of cytotoxic 3, 5-bis (arylidene)-4-piperidones and related N-acryloyl analogues. J. Med. Chem. 2001, 44, 586-593. [CrossRef] 
27. Al-Thamili, D.M.; Almansour, A.I.; Arumugam, N.; Mohammad, F.; Kumar, R.S. Functionalized N-Pyridinylmethyl Engrafted Bisarylmethylidenepyridinones as Anticancer Agents. Processes 2020, 8, 1154. [CrossRef]

28. Al-thamili, D.M.; Almansour, A.I.; Arumugam, N.; Kansız, S.; Dege, N.; Soliman, S.M.; Azam, M.; Kumar, R.S. Highly functionalized N-1-(2-pyridinylmethyl)-3,5-bis[(E)-arylmethylidene]tetrahydro-4(1H)-pyridinones: Synthesis, characterization, crystal structure and DFT studies. J. Mol. Struct. 2020, 1222. [CrossRef]

Sample Availability: Samples of the compounds $8(\mathbf{a}-\mathbf{h})$ are available from the authors.

Publisher's Note: MDPI stays neutral with regard to jurisdictional claims in published maps and institutional affiliations.

(C) 2020 by the authors. Licensee MDPI, Basel, Switzerland. This article is an open access article distributed under the terms and conditions of the Creative Commons Attribution (CC BY) license (http://creativecommons.org/licenses/by/4.0/). 